\title{
CORRECTION
}

\section{Correction to: Evolution and developmental plasticity of lung structure in high-altitude deer mice}

\author{
Claire M. West ${ }^{1} \cdot$ Catherine M. Ivy ${ }^{1} \cdot$ Renata Husnudinov ${ }^{1} \cdot$ Graham R. Scott $^{1}$ (D) \\ Published online: 23 October 2021 \\ ๑) Springer-Verlag GmbH Germany, part of Springer Nature 2021

\section{Correction to: \\ Journal of Comparative Physiology B} \\ (2021) 191:385-396 \\ https://doi.org/10.1007/s00360-021-01343-3
}

The article "Evolution and developmental plasticity of lung structure in high altitude deer mice" is part of the Special Issue Untangling the Oxygen Transport Cascade: A tribute to Peter Frappell ("Frapps") and it was inadvertently published in a different issue.

Publisher's Note Springer Nature remains neutral with regard to jurisdictional claims in published maps and institutional affiliations.

The original article can be found online at https://doi.org/10.1007/ s00360-021-01343-3.

Graham R. Scott

scottg2@mcmaster.ca

1 Department of Biology, McMaster University, Hamilton,

ON L8S 4K1, Canada 